\title{
PLASMA TESTOSTERONE LEVELS IN VASECTOMIZED RATS
}

\author{
E. J. MOGK, F. KAMEL, W. W. WRIGHT AND A. I. FRANKEL \\ Department of Biological Sciences, State University of New York at Binghamton, \\ Binghamton, New York 13901, U.S.A.
}

(Received 25th Fanuary 1975)

Conflicting reports based upon the indirect effects of vasectomy on plasma testosterone levels of the rat have recently been published. Sackler et al. (1973) reported decreased urinary ketosteroids and testicular weight after vasectomy of immature rats. Thakur et al. (1972) studied the fructose levels in the coagulating gland and maltase activity in the dorsolateral prostate gland in the mature rat after vasectomy and concluded that testosterone secretion increased. McGlynn \& Erpino (1974) found no change in sexual behaviour after vasectomy and concluded that there was no change in androgen production, as did Smith (1962) who reported a normal spermatogenic cycle in the vasectomized rat and Flickinger (1972) who found that vasectomy did not alter the ultrastructure of the rat testis. Direct measurements of plasma testosterone levels in men 3 months after vasectomy (Wieland et al., 1972; Bunge, 1972) and in rhesus monkeys 18 months after vasectomy (Resko \& Phoenix, 1972) supported the concept that vasectomy does not alter plasma testosterone concentrations.

In order to test the possibility that plasma testosterone concentrations are altered by vasectomy in the rat, 34 mature Sprague-Dawley rats weighing 250 to $300 \mathrm{~g}$ were allocated to three groups: Group I, eight unoperated rats; Group II, eight sham-operated rats; and Group III, eighteen vasectomized rats. Vasectomy was carried out under ether anaesthesia, using sterile conditions similar to those described by Heller \& Rothchild (1974). A single incision was made into the scrotal sac along the midline $1 \mathrm{~cm}$ posterior to the penis and secondary incisions were made into each testicular sac. The ductus deferens was exposed, blood vessels and fascia were dissected free from the straight portion, ligatures were tied $1 \mathrm{~cm}$ apart with 5-0 nylon thread, and $0.5 \mathrm{~cm}$ of the ductus deferens was removed between the ligatures. Sham surgery consisted of the same procedure, except that ligation and resection of the ductus were omitted. The scrotal incision was closed with 3 30 silk sutures.

Animals were 65 days old when the first blood sample was taken 1 week before surgery on 26 January 1973 directly from the heart under light ether anaesthesia. Blood samples were then taken 2, 4, 8, 12, 20, 24 and 29 weeks after vasectomy at the same time of day for each animal, all blood being taken between 10.00 and 12.00 hours. Animals were housed two to a cage under a 12-hr light/12-hr dark schedule (lights on at 06.00 hours) at $72^{\circ} \mathrm{F}$, and were given free access to Purina Rat Chow. Plasma testosterone levels were determined by radioimmunoassay (Frankel et al., 1975). During the collections of 
blood, one rat from Group I, four from Group II and three from Group III died.

The animals were autopsied 30 weeks after surgery, and the testes, epididymides, ventral prostate glands, coagulating glands and seminal vesicles were dissected out and weighed. As reported earlier (Flickinger, 1972) there was a high incidence of yellowish granulomata (14/15) at the proximal ligature or in the cauda epididymidis in Group III. Granulomata in the epididymis were associated with gross testicular pathology, including atrophy or total degeneration of the testis. No granulomata were seen in rats in Groups I and II.

The development of granulomata in the cauda epididymidis in 4/15 rats was probably due to the technique since vasectomy resulted in the resection of the nerves to the epididymides. Similar granulomata in the cauda epididymidis have been produced in rats treated with guanethidine, a drug that specifically destroys the nerves innervating the accessory sex organs (Evans et al., 1972). Resection of these nerves may be an even greater problem in immature animals and may account for the results of Sackler et al. (1973).

Table 1. Comparison of sex organ weights (mean \pm S.E.M.) in male rats 30 weeks after surgery

\begin{tabular}{|c|c|c|c|c|c|c|c|}
\hline Group & $\begin{array}{l}\text { No. of } \\
\text { rats }\end{array}$ & $\begin{array}{l}\text { Testis } \\
(\mathrm{g})\end{array}$ & $\begin{array}{l}\text { Epididymis } \\
(\mathrm{g})\end{array}$ & $\begin{array}{c}\text { Seminal } \\
\text { vesicle } \\
(\mathrm{mg})\end{array}$ & $\begin{array}{c}\text { Ventral } \\
\text { prostate } \\
(\mathrm{mg})\end{array}$ & $\begin{array}{l}\text { Coagulating } \\
\text { gland } \\
(m g)\end{array}$ & $\begin{array}{l}\text { Body } \\
w t \\
(g)\end{array}$ \\
\hline $\begin{array}{l}\text { Group I } \\
\text { (unoperated) }\end{array}$ & 7 & $\begin{array}{r}3.5385 \\
\pm 0.1732\end{array}$ & $\begin{array}{r}1.4915 \\
\pm 0.0612\end{array}$ & $\begin{array}{r}524 \cdot 3 \\
\pm 33.6\end{array}$ & $\begin{array}{r}683 \cdot 4 \\
\pm 20 \cdot 1\end{array}$ & $\begin{array}{r}203.2 \\
\pm 18.1\end{array}$ & $\begin{array}{r}554 \cdot 2 \\
\pm 22.8\end{array}$ \\
\hline $\begin{array}{l}\text { Group II } \\
\text { (sham-operated) }\end{array}$ & 4 & $\begin{array}{r}3.4698 \\
\pm 0.2146\end{array}$ & $\begin{array}{r}1.3981 \\
\pm 0.1460\end{array}$ & $\begin{array}{r}492 \cdot 4 \\
\pm 36 \cdot 4\end{array}$ & $\begin{array}{r}558 \cdot 0 \\
\pm 28 \cdot 8\end{array}$ & $\begin{array}{r}141 \cdot 0 \\
\pm 24 \cdot 1\end{array}$ & $\begin{array}{r}590.5 \\
\pm 15.5\end{array}$ \\
\hline $\begin{array}{l}\text { Group III } \\
\text { (vasectomized) }\end{array}$ & 10 & $\begin{array}{r}3.5690 \\
\pm 0.1108\end{array}$ & $\begin{array}{r}1.3000 \\
\pm 0.0370\end{array}$ & $\begin{array}{r}491.9 \\
\pm 27.4\end{array}$ & $\begin{array}{r}513 \cdot 4 \\
\pm 56 \cdot 4\end{array}$ & $\begin{array}{r}171 \cdot 4 \\
\pm 8 \cdot 4\end{array}$ & $\begin{array}{r}553 \cdot 1 \\
\pm 26 \cdot 7\end{array}$ \\
\hline Significance* & & N.S. & $P<0.0569$ & N.S. & $P<0.0529$ & $P<0.0548$ & N.S. \\
\hline
\end{tabular}

* Measured by one-way analysis of variance.

A comparison of organ weights is shown in Table 1. Four rats with epididymal granulomata and one rat with a unilateral cryptorchid testis due to a large abdominal granuloma were excluded from the results for Group III since the organs were either atrophied or the granulomata distorted the weights. There was a general decrease in organ weights after surgery. The testicular weights are in agreement with those reported by Plaut (1973) and McGlynn \& Erpino (1974).

Plasma testosterone levels in the three groups were not significantly different during the 29 weeks after surgery (Text-fig. 1). The elevation in testosterone concentration in all rats at the beginning of the experiment was due to seasonal variation and was not the result of either blood collection or vasectomy (Mock \& Frankel, 1974). These results show that vasectomy does not alter testosterone secretion as was previously suggested (Sackler et al., 1973; Thakur et al., 1972) and corroborate reports on unchanged testosterone levels in vasectomized men (Wieland et al., 1972; Bunge, 1972). 


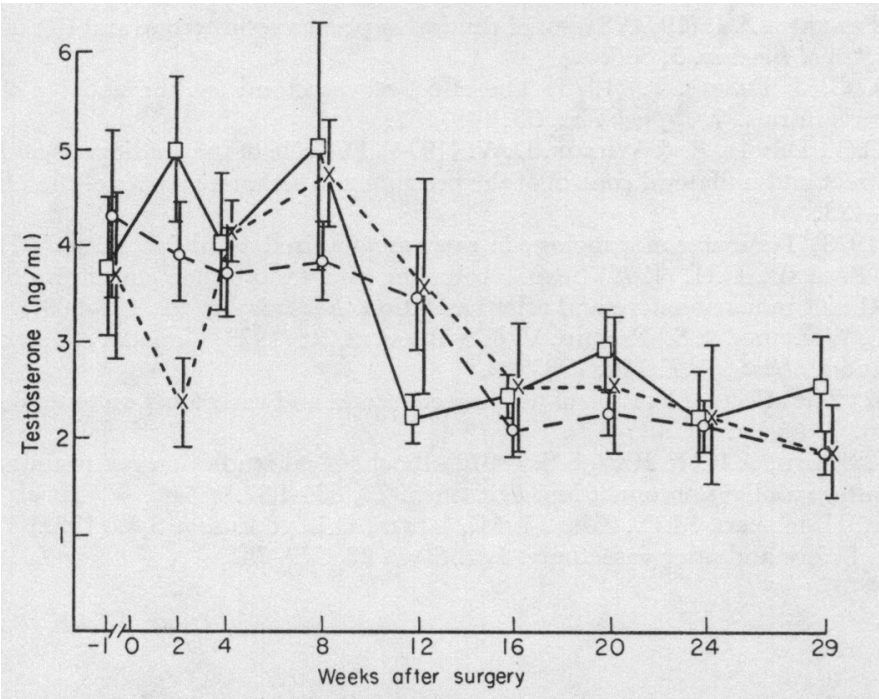

TEXT-FIG. 1. Comparison of plasma testosterone levels in unoperated ( $\square$ ), shamoperated $(x)$ and vasectomized $(0)$ rats. Vertical bars represent the S.E.M. There was no significant difference among the three groups, as analysed by a $3 \times 9$ factorial analysis of variance for repeated measures.

Reduction in the weights of the accessory sex organs cannot be attributed to a decrease in general circulating levels of testosterone. The weight loss observed is more likely due to a decrease in testosterone reaching these organs by means of the ductus deferens (Pierrepoint \& Davies, 1973; Pierrepoint et al., 1974). The source of the testosterone could either be from epididymal synthesis (Hamilton \& Fawcett, 1970) or by concentration in the epididymis of testicular androgen, as was demonstrated in the rabbit (Frankel \& Eik-Nes, 1970). A possible surgical effect is also indicated since organ weights in the rats in Group II (sham-operated) were generally intermediate between those of Group I and Group III rats.

This study was supported in part by grants from USPHS (HD04081) and NIMH (MH13058).

\section{REFERENCES}

Bunge, R.G. (1972) Plasma testosterone levels in man before and after vasectomy. Investve Urol. 10, 9. Evans, B., Gannon, B.J., Heath, J.W. \& Burnstock, G. (1972) Long-lasting damage to the internal male genital organs and their adrenergic innervation in rats following chronic treatment with the antihypertensive drug guanthidine. Fert. Steril. 23, 657-667.

Fliakinger, C.J. (1972) Ultrastructure of the rat testis after vasectomy. Anat. Rec. 174, 477-493.

Frankel, A.I. \& Erk-Nes, K.B. (1970) Testosterone and dehydroepiandrosterone in the epididymis of the rabbit. 7. Reprod. Fert. 23, 441-445.

Frankel, A.I., Mock, E.J., Wright, W.W. \& Kamel, F. (1975) Characterization and physiological validation of a radioimmunoassay for plasma testosterone in the male rat. Steroids 25, 73-98.

Hamilton, D.W. \& FawcetT, D.W. (1970) In vitro synthesis of cholesterol and testosterone from acetate by rat epididymis and vas deferens. Proc. Soc. exp. Biol. Med. 133, 693-695.

Heller, G.V. \& RothanmD, I. (1974) The influence of the surgical technique used for vasectomy on testis function in rats. $\mathcal{F}$. Reprod. Fert. $39,81-84$.

McGlynn, J.M. \& ERPino, M.J. (1974) Effects of vasectomy on the reproductive system and sexual behaviour of rats. 7. Reprod. Fert. 40, 241-247. 
Mock, E.J. \& Frankel, A.I. (1974) Seasonal rhythm in plasma testosterone and LH of male laboratory rats. 7. Steroid Biochem. 5, 386.

Pierrepoint, C.G. \& Davies, P. (1973) The effect of vasectomy on the activity of prostatic RNA polymerase in rats. $\mathcal{J}$. Reprod. Fert. 35, 149-152.

Pierrepoint, G.G., Davies, P. \& Wilson, D.W. (1974) The rôle of the epididymis and ductus deferens in the direct and unilateral control of the prostate and seminal vesicles of the rat. $\mathcal{F}$. Reprod. Fert. 41, 413-423.

Plaut, S.M. (1973) Testicular morphology in rats vasectomized as adults. Science, N.Y. 181, 554-555.

Resko, J.A. \& Phoenix, C.H. (1972) Sexual behavior and testosterone concentrations in the plasma of the Rhesus monkey before and after castration. Endocrinology 91, 499-503.

Sackler, A.M., Weltman, A.S., Pandhi, V. \& Schwartz, R. (1973) Gonadal effects of vasectomy and vasoligation. Science, N.Y. 179, 293-295.

Sмrтн, G. (1962) The effects of ligation of the vasa efferentia and vasectomy on testicular function in the adult rat. J. Endocr. 23, 385-399.

Thaxur, A.N., Sheth, A.R. \& Rao, S.S. (1972) Biochemical studies on rat testes and sex accessory organs after vasoligation operation. Fert. Steril. 23, 834-837.

Wieland, R.G., Hallberg, M.G., Zorn, E.M., Klein, D.E. \& Luria, S.S. (1972) Pituitary-gonadal function before and after vasectomy. Fert. Steril. 23, 779-781. 